\title{
Study on college English teaching under new media
}

\author{
Zhimei Zhao
}

AIEN International Institute, Dalian Jiaotong University, Dalian, 116021, China

\section{Keywords: new media; college English; teaching}

\begin{abstract}
In view of continuous technological development in recent years, new media enter modern life. Wide application of new media, outstanding effects and rapid generalization make people exclaim in great surprise. Under such new situation, fusion of college English teaching in new media teaching can well improve effects of English teaching. This paper analyzes main features of new media, discusses current situation of college English teaching under new media and proposes college English teaching strategy under new media.
\end{abstract}

\section{Introduction}

English course has become a required course of colleges. College students not just have the pressure of CET-4 and CET-6, but also have more needs such as graduate school examination and going abroad. But, English class hours in colleges are very limited. Besides, increased university enrollment leads to intense educational resources. Thus, college English teaching is faced with low efficiency for a long time. How to improve college English teaching effects has become a hot issue of the whole society. With continuous technological development, new media start to rise. Due to instantaneity, interaction and richness features of new media, it has great advantage in English teaching.

\section{Main features of new media}

New media mainly refer to new type of media form with digital technique and network technique as important support and LAN, network technique and communication equipment as the main approaches. The patterns of manifestation include digital journal, SMS, WeChat and microblog etc. Compared with traditional media, new media have distinct features.

Firstly, convenience. The most important feature of new media is that users can gain and browse information more conveniently. Thus, the life style and rhythm of modern people are greatly changed so that people can know all things without going out. Besides, people can buy well-content products at home. Learners can learn the knowledge that it is hard for them to contact in classroom via new media.

Secondly, instantaneity. New media will not be limited by space and time like traditional media and show more flexible and fast. Information can be published anytime. Besides, information contents can be timely updated. Meanwhile, instantaneity of new media is also reflected in feedback instantaneity, which cannot be reached by traditional media.

Thirdly, interaction. One of outstanding features of new media is prominent interaction. New media can break through single-direction dissemination way of traditional media. Thus, traditional media lose discourse hegemony. New media make more media users communicate via mobile phone and network and make them express their opinions. New media provide new development impetus for social progress.

Fourthly, integration. New media can not just recombine scattered information such as voice frequency, video frequency and text to make information more vivid, but also integrate TV, computer and sound equipment so that information system can achieve sharing and resources can be better allocated.

Fifthly, richness. New media are all-encompassing in terms of contents, ranging from talks of national leaders and daily life of common people. Meanwhile, new media transmission form is not limited to news report of traditional media any longer, but also includes new forms such as 
microblog and WeChat.

It is because of so many distinct characteristics of new media that new media receive more and more social attention in recent years.

\section{Current situation of college English teaching under new media}

At present, new media have become newly-developing hot media in life of modern people, especially as smartphone and portable media popularize comprehensively. This marks China has entered brand-new new media era. College students who dare to try and accept new things are one of important user groups of new media. Nowadays, every college student has a smartphone. More than half college students have their own laptops. Many have tablet PC. Daily data retrieval, interaction and entertainment of college students are conducted via computer, mobile phone and other new media tools. So, their learning habits will inevitably be influenced by new media. Compared with traditional paper media, reading advantage of new media is more obvious. College students fond of new media mainly adopt simple and relaxing reading modes with strong entertainment. Reading utilitarian nature is quite strong.

By contrast, English course is a required course and has a very important position. It is required to integrate and optimize English knowledge learned in primary school and middle school. Meanwhile, it is required to make college students transform from examination-oriented English to autonomous English study through practice of English phonetics, grammar and vocabulary. This requires college students deeply learning English text, and clearly cognizing English cultural background, writing methods, grammar knowledge points, sentence patterns and vocabulary. Besides, students should proficiently apply listening, speaking, reading, writing and translation in practical teaching. College students must achieve accurate mastery of English language through studying hard and repeated learning. Many students have resistance emotion and fear difficulties during English study. They are unwilling to study and cannot learn well. English teachers are difficult to get rid of the conflict between the particularity of English teaching and learning form under new media. So, the difficulty in English teaching increases.

\section{College English teaching strategies under new media}

\section{(I) Application of online corpus in college English teaching}

Since the vocabulary is the foundation of language, English vocabulary learning should start from pronunciation, the meaning of a word, collocation and style color to enhance communication with college students. Meanwhile, language style awareness of college students is poor, so they often apply oral vocabularies in written language. Constant popularization of network causes that English coursed resources available become increasingly rich. Next, English vocabulary teaching with network media will be discussed from two aspects: synonym teaching and synonym analysis.

1) Synonym teaching. English is a language with very rich synonyms. Every word will have more than 10 and even tens of synonyms. Students will not apply English vocabulary, which is an important cause of low English level. In English writings of college students, the word "important" can be often seen. Since this word is applied too frequently, it is called "a sick word". COCA can help learners solve the problem of deficient synonyms. After learners open COCA, they can input [= important] in WORD column below SEARCH STRING in the webpage. Learners can see all synonyms of important through clicking SEARCH. A total of 18 synonyms are searched. Through this method, college students can learn all synonyms of important in the shortest time so that they can have richer lexical library for selection when expressing "important".

2) Synonym analysis. Synonyms can make language become richer. Meanwhile, some learning obstacles occur for English learners. A large number of synonyms in English have great differences in collocation and emotional color. So, the advantage of COCA in synonym analysis will be discussed by taking legal and legitimate for example. After retrieving legitimate, the nouns which can be modified by this word mainly include: government, concern, question, authority, interest businesses and power etc. Through careful observation, it can be seen that only a few words can be 
modified by the two adjectives, including right, issue and authority etc. Although the Chinese meaning of the two words is "legitimate", the nouns modified by the two words have great differences.

\section{(II) Application of microblog in college English teaching}

Since modern science and technology advance rapidly and the economy continuous to develop, the proportion of college students surfing the internet with mobile phone becomes increasingly high. 3G and 4G communication technology bring comprehensive reform for surfing the internet with mobile phone. Contemporary college students are generally high on refreshing microblog and publishing comments. In fact, college English teachers can encourage college students to apply microblog to carry out English course teaching. The specific method is as follows: 1) positively encourage college students to write English microblog diary. The thought of college students is very active. They can receive massive information every day. Besides, they take delight in expressing their ideas. So, college students can release their opinions on a problem through microblog in the form of short English diary and communicate with other teachers and students. 2) Release relevant English study contents. English teachers can release excellent English articles, new words and hot words they collect on microblog. It is required to actively encourage college students to release interesting English they learn so as to make English study not boring any longer. 3) Discuss via microblog. English teachers can release next class contents on microblog in advance, guide them to discuss on microblog and stimulate their learning enthusiasm. Meanwhile, students can discuss what they learn. Such communication mode can make learners learn in loose and harmonious atmosphere. Of course, college students can release the problems they encounter on microblog and make teachers and students solve them. 4) teaching-learning feedback platform can be set with microblog. College students can apply this platform to comment the lesson objectively and propose corresponding suggestions. Teachers can feed learning opinions back to students. Compared with traditional learning mode, college students can gain more attention from teachers through the microblog platform so as to enhance learners' learning enthusiasm.

\section{(III) Application of WeChat in college English teaching}

WeChat is a network communication tool developing recently. The development speed is amazing. Nowadays, it has become an indispensible new communication tool for daily communication including college student group. WeChat regards network as the media and comprehensively supports users to send text, picture, voice frequency, video and voice SMS. WeChat enriches and simplifies communication mode of mobile phone users. It can be completely applied in listening, speaking, reading and writing in college English teaching. Powerful functions of WeChat make college students and teachers apply it with proficiency. English teachers can apply WeChat platform to release English grammar or latest social news and let students discuss in English. This can greatly motivate resonance of college students and improve learning and speaking ability of college students. Meanwhile, English teachers apply WeChat to participate in guidance and supervision. Besides, teachers can release official dynamics to enhance the learning contents, make college students better master emphases and difficulties in English study and guide college students to improve reading and writing ability. The above English teaching form via WeChat is actually a teaching method combining input and output. It is also one of significant teaching methods for college English teaching. It can well boost English learning interest of college students.

\section{(IV) Application of micro-video in college English teaching}

Due to very strong sense of image and infection, micro-video becomes a significant application of new media. In view of continuous development of international internet technique and rapid popularization of various mobile terminals as well as the continuous drop of network expense in recent years, surfing the internet and watching video with mobile phone anytime and anywhere have become significant life state for college students. In this way, micro-video receives more and more attention. Micro-video generally refers to the video with short play time, including micro-film, micro-documentary or film and television editing. They can also be played with computer, mobile phone or MP4. There are many micro-videos suitable for college English teaching, such as micro-video MTV, New Concept English and Friends. All these are English study resources for 
college students. To better learn English, college students can download micro-videos in mobile phone or directly watch them via internet. Learning English with micro-videos can greatly improve listening and speaking ability of college students. Of course, through watching original short films of British and American countries, college students can also learn pure Britain and America culture and boost intercultural communication competence of college students.

\section{Conclusions}

Generally speaking, as new media spread rapidly, brand-new opportunities and challenges are brought for college English teaching. College students as the masters in the $21^{\text {st }}$ century should take the initiative to apply new media to enhance English teaching. College English teachers should continuously learn the latest new media knowledge, and fully apply new media to communicate and interact with college students so as to perfect English education system and improve English classroom teaching effects.

\section{References:}

[1] Li Xia, Analysis of application of new media resources in college English teaching [J]. News Knowledge, 2012 (1)

[2] Wei Jiaqin, Analysis of extension and innovation of English language under new media perspective [J]. Theory Research, 2012 (16)

[3] meng Ziyan, Actively cope with impacts of new media on college English teaching [J]. Academic Journal of Shanxi Provincial Committee Party School of C.P.C, 2013 (4)

[4] Jia pengfei, On vocational English teaching under new media background [J]. Journal of Xingtai Polytechnic College, 2013 (6)

[5] Wang Li, Exploration and practice of English visual-audio-oral teaching mode based on new media [J]. Journal of Changchun Teachers College, 2014 (3) 